\title{
Student Perspectives of Technology use for Learning in Higher Education
}

\author{
(Perspectivas de los estudiantes sobre el uso de \\ la tecnología para el aprendizaje en la educación \\ superior)
}

\author{
Nada Dabbagh \\ Helen Fake \\ Zhicheng Zhang \\ George Mason University (USA)
}

DOI: http://dx.doi.org/10.5944/ried.22.1.22102

\section{How to reference this article:}

Dabbagh, N., Fake, H., \& Zhang, Z. (2019). Student Perspectives of Technology Use for Learning in Higher Education. RIED. Revista Iberoamericana de Educación a Distancia, 22(1), pp. 127-152. doi: http://dx.doi.org/10.5944/ried.22.1.22102

\begin{abstract}
In this study, college students in a large public university in the U.S. were surveyed regarding what technologies they use most frequently for learning, what technologies they value for learning, and how they perceive technology effectiveness to support their learning. The results revealed that technology use and value were closely aligned with laptops and these were detailed as the most used and valued for learning, which underscores the importance of mobile and portable devices in supporting anytime anywhere learning. In terms of using software for learning, search engines, file-sharing tools, digital libraries, videos, and wikis obtained the best results, suggesting that students are adopting self-directed, approaches to their learning. Additionally, collaboration tools were perceived as the most important for learning which highlights the need to design better teaching strategies and learning interactions to support collaborative practices that use technology. Overall, the majority of participants perceived that technology was effective in fostering discussion, collaboration, and interaction. This enable experiential learning, supporting organization, planning, and resource management, and facilitating a personalized learning experience. The results also revealed statistically significant differences between the experiences of undergraduate and graduate students about the effectiveness of technology. Implications for integrating Web 2.0 technologies into teaching and learning practices are discussed.
\end{abstract}

Keywords: Web 2.0; Social Media Technologies; Technology Use for Learning; Learning Technologies; Technology Effectiveness; Personal Learning Environments PLEs; Higher Education. 


\section{Resumen}

En este estudio, los estudiantes universitarios en una gran universidad pública en los EE. UU. fueron encuestados con respecto a qué tecnologías utilizan con más frecuencia para aprender, qué tecnologías valoran para el aprendizaje y cómo perciben efectividad de la tecnología para respaldar su aprendizaje. Los resultados revelaron que el uso y el valor de la tecnología estaban estrechamente alineados con ordenadores portátiles y teléfonos inteligentes, éstos fueron detallados como los más utilizados y valorados para el aprendizaje, lo que subraya la importancia de los dispositivos móviles y portátiles para respaldar el aprendizaje en cualquier momento y lugar. En términos de uso de software para el aprendizaje, los motores de búsqueda, las herramientas para compartir archivos, las bibliotecas digitales, los videos y los wikis obtuvieron los mejores resultados, lo que sugiere que los estudiantes están adoptando enfoques autodirigidos para su aprendizaje. Además, las herramientas de colaboración fueron percibidas como las más importantes para el aprendizaje, lo que destaca la necesidad de diseñar mejores estrategias de enseñanza e interacciones de aprendizaje para respaldar las prácticas de colaboración que utilizan la tecnología. En general, la mayoría de los participantes percibió que la tecnología era eficaz para fomentar el debate, la colaboración y la interacción. Esto permite el aprendizaje experiencial, apoya la organización, la planificación, la gestión de recursos y facilita una experiencia de aprendizaje personalizada. Los resultados también revelaron diferencias estadísticamente significativas entre las experiencias de los estudiantes de pregrado y posgrado acerca de la efectividad de la tecnología. Se discuten las implicaciones para integrar las tecnologías Web 2.0 en las prácticas de enseñanza y aprendizaje.

Palabras-claves: web 2.0; tecnologías de medios sociales; uso de la tecnología para el aprendizaje; tecnologías de aprendizaje; efectividad de la tecnología; entornos de aprendizaje personales PLE; educación superior.

In January 2017, the Office of Educational Technology of the United States Department of Education issued a supplement to the 2016 National Education Technology Plan (NETP) that calls for reimagining the role of technology in higher education in a way that embraces the needs of an increasingly diverse and geographically dispersed group of students with differing educational goals seeking access to high quality postsecondary learning experiences and credentials. A principal recommendation of this report is to think about technology as an engaging and empowering learning agent such that:

All learners will have engaging and empowering learning experiences in both formal and informal settings, in multiple contexts, and at various stages throughout their lifetimes. Learners will be supported by technology that scaffolds their learning, allows them to document their competencies, and helps them form meaningful connections to instructors, mentors, and peers to ensure their success along diverse career and educational pathways (p. 17). 
Reimagining the role of technology as an engaging and empowering learning agent allows faculty, administrators, and instructional designers to provide learning experiences that are more personalized and directly relevant to students' needs, goals, and interests; more continuous, fostering personal growth and lifelong learning skills; and more flexible, enabling fluid transitions between formal and informal learning and college and career pathways. However, this requires a rethinking of the teaching and learning affordances of technology and an understanding of how faculty and students are using technology for learning. For example, pre-Internet technologies as film, television, compressed video and presentation software, also known as broadcast technologies, were effective in transmitting information to students and hence were primarily used by the instructor or the computer system to support teacher-centered and content-centered pedagogical practices. With the onset of ICT (Information Communication Technology) and the Internet, technology evolved from static and one-way provision of content to dynamic and participatory mediums enabling teaching and learning to be distributed over time and place synchronously and asynchronously and supporting multiple forms of interaction such as learner-learner, learner-group, learner-content, and learner-instructor (Dabbagh et al., 2016).

Technology evolved again in the $21^{\text {st }}$ century to what we have come to know as Web 2.o technologies and while many of the inherent teaching and learning affordances of ICT were retained, Web 2.0 technologies represented a qualitative shift in how information is created, delivered, and accessed. Web 2.0 became as much a concept as a technology, embodying characteristics such as openness, personalization, collaboration, social networking, social presence, and user-generated content (Adell \& Castaneda, 2010; Barron, 2006; Dabbagh \& Kitsantas, 2012; Dabbagh et al., 2016; Haskins, 2007; van Harmelen, 2008). Web 2.0 is also characterized as the "social web" and described as the second stage of Internet growth that is all about connecting people and "putting the "I" in the user interface and the "We" into Webs of social participation" (Davis, 2008, p. 3). As a result of these affordances, a new class of technologies labeled social media technologies was established (NMC, 2017). Examples of social media technologies include resource finding, organizing, and sharing tools that enable online bookmarking, blogging, and microblogging (e.g., del.icio.us, WordPress, Twitter); collaboration tools that enable online creation and organization of collaborative workspaces (e.g., wikis, Google Docs); media sharing tools that enable the creation and sharing of digital media and artifacts (e.g., Pinterest, YouTube); and social networking sites that enable socializing and networking (e.g., Facebook, Google+). Social media technologies are ever present in all parts of society including the education sector and are changing how students and educators interact, present information, and judge the quality of content and contributions (Dabbagh et al., 2016).

More specifically, social media technologies are empowering students to take charge of their own learning, prompting them to create, organize and package 
learning content around their goals, interests, and preferences resulting in learning that is increasingly self-directed and personalized (Dabbagh \& Kitsantas, 2012; Johnson, Adams, \& Haywood, 2011). Consequently, higher education institutions are integrating social media technologies and platforms as ICTs to support learnercentered and personalized education systems. Additionally, emergent patterns of learning interactions are evolving towards the use of multiple technologies, multiple platforms, and multiple devices, making it increasingly difficult for faculty and educational institutions to control the learning environment (Pardo, 2013). Dede and Grimson (2013) posit that learners and instructors in higher education contexts are using ICTs as 'bricoleurs', "improvising what they need from the broad palette of tools 'ready to hand' in their everyday experience, whether social networks, cloud computing tools, mobile apps, physical meet-ups, or other emerging resources" (p. 4). Given the omnipresence of Web 2.0 technologies in higher education and the emergent learning affordances, more research is needed to better understand what digital technologies college students are using and how they are using these technologies for learning in order to inform our teaching and learning practices.

\section{RESEARCH ON SOCIAL MEDIA TECHNOLOGIES}

Research indicates that social media technologies are being increasingly used as tools for developing formal and informal learning spaces or experiences that start out as an individual learning platform, digital space, or Personal Learning Environment (PLE) enabling individual knowledge management and construction, and evolve into a social learning platform, system, or Personal Learning Network (PLN) where knowledge is socially constructed and mediated (Dabbagh \& Reo, 2011; Kitsantas \& Dabbagh, 2010; Minocha \& Kerawalla, 2011). Although not wedded to a particular technology, PLEs and PLNs are primarily facilitated by cloud-based Web 2.o technologies and services designed to help students create, organize, and share content, participate in collective knowledge generation and manage their own meaning-making (Dabbagh \& Reo, 2011; Martindale \& Dowdy, 2010).

Dabbagh and Kitsantas (2013) examined adult professionals' general use of social media technologies and more specifically, how adult professionals use social media technologies to create PLEs to achieve their learning goals. The findings showed that participants $(\mathrm{N}=87)$ tended to use blogs, wikis, and social media sharing technologies primarily for personal learning $(70 \%, 60 \%, 62 \%$ respectively); social networking sites primarily for socializing and networking (72\%, 60\%); and games and social media sharing technologies primarily for entertainment (88\%, 76\%). With respect to PLE and PLN development, blogs, microblogs, and social bookmarking tools were perceived as more useful for personal information management, whereas wikis, cloud-based technologies, social networks, and social media sharing tools were perceived as more useful for social interaction and collaboration. In a followup study, Dabbagh, Kitsantas, Al-Freih, and Fake (2015) examined the processes 
that college students' use to create PLEs and PLNs using social media technologies and whether social media technologies are effective learning tools. The findings of this study revealed that students engaged in the self-regulated learning processes of goal setting, task strategies, self-monitoring, and self-evaluation while using social media technologies to develop PLEs and PLNs. Additionally, students reported being intrinsically motivated in using social media technologies to create PLEs and PLNs which is not surprising given that social media's ability to motivate people to learn through community engagement and inter-group communications has been well documented (Mason \& Rennie, 2007; McLoughlin \& Lee, 2010; Minocha \& Kerawalla, 2011).

With respect to what digital technologies college students use for learning, Dabbagh and Fake (2017) analyzed the blog posts of 109 college students (75 undergraduate and 34 graduate) that consisted of responses to the following questions: Who are you, and what do you like to learn about; what hardware do you use to learn; what software do you use to learn; what digital tools do you wish you had access to for learning; and what might your ideal personal learning environment (PLE) look like. The findings of this study revealed that overall, students reported using laptops and smartphones for learning citing portability and connectivity as key advantages of these mobile devices. Interestingly, tablets were more popular among graduate students while smartphones were more popular with undergraduates. With respect to software use for learning, search engines were ranked highest by undergraduates followed by social networking sites and online videos, while graduate students ranked online videos highest followed by search engines and eBooks. Blogs, podcasts, mobile apps and digital libraries were the least used for learning across both populations in this study.

When asked what digital tools they wished they had access to for learning, students wished they had access to organizational tools such as graphic organizers, concept mapping software, and infographic tools to help them visually represent and organize their learning, followed by progress tracking tools to help them stay on track with expectations, and resource management tools such as online bookmarking to help them aggregate and organize learning resources. These findings align with the results of a study conducted by Parra (2016) in which college students reported that they highly valued digital tools that supported information organization and resource management for PLE development. Finally, analysis of responses to the last question in the 2017 Dabbagh and Fake study revealed that students' ideal PLE is dependent on the capability of technology to (1) foster discussion, collaboration, and interaction, (2) enable experiential learning, (3) support organization, planning, and resource management, and (4) facilitate a personalized learning experience.

Given these recent research findings and the inherent capabilities and affordances of social media technologies in supporting user-generated content, shareable content, personal knowledge management, collective knowledge generation, and social interaction and collaboration, the researchers of this current study sought to 
further examine the validity and generalizability of college students' perceptions of the value and effectiveness of technology in supporting their learning and the types of technologies students use most frequently for learning. Therefore, this study examined three research questions:

1. What technologies do college students use most frequently for learning?

2. What technologies do college students value for learning?

3. How effective are technologies in fostering discussion, collaboration, and interaction, enabling experiential learning, supporting organization, planning, and resource management, and facilitating a personalized learning experience?

\section{METHOD}

In order to address these research questions at scale, a survey methodology was employed. Survey methodology enables researches to gather cross-sectional data from a representative sample of the targeted population. Survey methodology is a common research method in higher education contexts given the arge number of students attending colleges and universities resulting in large sample sizes. For this study, were able to pull approximately a $30 \%$ stratified random sample to ensure that the sample was representative of the target population. At $99 \%$ confidence level, the confidence interval for this sample size is 1.03. Additionally, survey methodology enables multiple types of statistical analyses such as descriptive, categorical, and comparative. The next paragraphs in this paper describe the participants of this study, survey development, recruitment procedure and data analysis.

\section{Participants}

Research participants included graduate and undergraduate students at a large public university in the US with a student population of approximately 35,000. The participant sample was selected from a stratified sample of 10,928 students that were demographically representative of the student population at this university. It is important to note that the university where the survey was administered is considered ethnically diverse nationwide with a student body composition that is far above the national average. The original response rate to the survey was $6 \%(\mathrm{~N}=622)$ however responses declined over time with $n=463$ completing the survey. All figures represented in this report have adjusted the numbers based on the total number of respondents to the individual survey question to ensure the most accurate reporting.

While it is common to see response attrition for long surveys, the decline in participation was attributed to a variety of factors beyond survey fatigue and drop-off. For example, students who indicated that they were not eligible to participate (e.g. were under the age of 18 or did not consent to the data collection) were immediately 
branched to the end of the survey. It is also possible that participants skipped certain items, failed to answer others, or simply discontinued answering the questions over time. As mentioned previously, in response to survey response attrition, we adjusted our data analysis on a question by question basis. We additionally utilized and reported the valid percentage to control for nonresponse error.

Female and white students were slightly over-represented in the respondents compared to the university student population and the stratified random sample selected for this study (e.g., $61 \%$ respondents were female vs. $52 \%$ in the sample; $52 \%$ respondents were white vs. $45 \%$ in the sample). Therefore, it is important to note that the viewpoints of individuals from these demographics will be more heavily represented in this analysis. Also, of the responding sample, $41 \%$ were between the ages of $18-21$. The second largest age group included $22-25$-year-olds (21\%). See Figure 1.

Figure 1. Participant age distribution

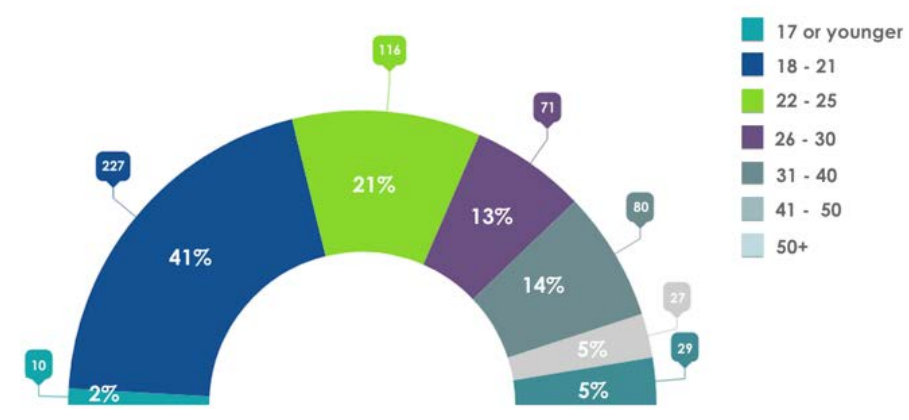

The largest percentage of responses were collected from Master's degree students (26\%) while freshmen, juniors, and seniors responded at a similar rate (about $18 \%$ for each category). Professional students had the lowest response rate at $2 \%$. Doctoral students represented $10 \%$ of the population. See Figure 2. 
Figure 2. Participant academic year

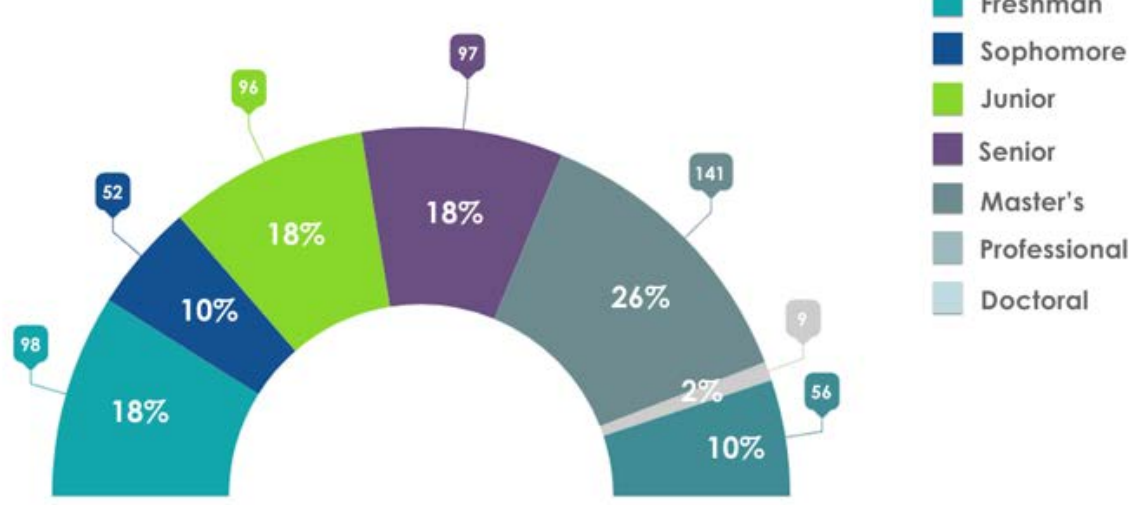

The sample also represented a range of academic majors. The most popular majors for participants of this study included Undecided and Other Majors (13\%), followed by Business, Management, Marketing (12\%), Computer and Information Sciences and Social Sciences (11\%). The least popular majors comprised Communications/ Journalism and Liberal Arts/General Studies (1\%). See Figure 3.

Figure 3. Participant academic major

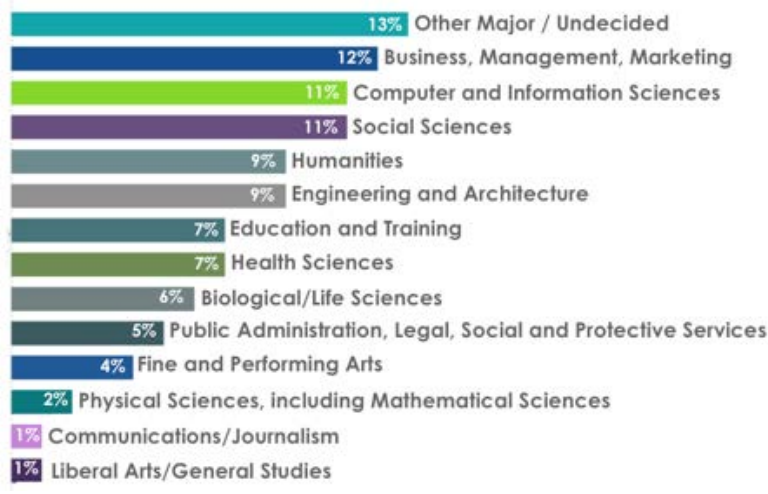




\section{Instrument}

The researchers developed the Technology Use for Learning Student Survey, a survey grounded in the literature regarding the classifications of Web 2.0 technologies and based on the four ideal PLE characterization themes that emerged from the qualitative data analysis of the Dabbagh and Fake (2017) study mentioned earlier. The Technology Use for Learning Student Survey consisted of 11 questions and 101 items (see Appendix). The first few questions of the survey (Questions 1-3) focused primarily on demographic and descriptive data. Questions 4 and 6 queried students about what hardware and software tools they use to learn. Questions 5 and 11 sought to measure the value (importance) students placed on learning technologies using a 6-point Likert scale. Finally, Questions $7-10$ of the survey also used a 6-point Likert scale to evaluate students' perceived effectiveness of learning technologies. Statements for Questions $7-10$ were generated based on the actual phrases written by students in the blog posts analyzed in the Dabbagh and Fake (2017) study and based on a literature review of the learning affordances associated with the four "ideal PLE" characterization or technology effectiveness themes or categories of (1) fostering discussion, collaboration and interaction; (2) enabling experiential learning; (3) supporting organization, planning, and resource management; and (4) facilitating a personalized learning experience. For example, for the category fostering discussion, communication, and interaction, one of the statements questioned students' perceived satisfaction with technologies enabling them to "feel connected to other learners".

\section{Procedure}

A pilot version of the Technology Use for Learning Student Survey was sent out to students in the College of Education and Human Development (CEHD) of the university in which the study was conducted in order to refine the questions and iterate on how to best capture the information to support the research questions. After receiving permission from the university's Institutional Review Board, the researchers distributed the pilot version of the survey to CEHD students. Upon receiving the results of the pilot survey, the researchers evaluated any anomalies and revisited the results to determine if there might have been any areas of confusion in the questions. The researchers then contacted the university's Office of Institutional Research and Effectiveness (OIRE) which agreed to disseminate the survey to university students at large in the fall semester of 2017.

After all the necessary approvals and timelines were agreed upon, the survey was sent to a $30 \%$ stratified random sample of the student population pulled from the institutional database. The survey was sent in October of 2017 to reduce potential overlap with other large institutional surveys. Once survey participants clicked the survey link, they were asked to acknowledge their consent. If they did not indicate 
consent, they were automatically directed to the end and thanked for their time. This was also true if students were under the age of 17 . Of note, no incentives were offered to encourage increased participation. Rather, to increase the response rate, three reminders were sent by OIRE to students to request their participation. As noted earlier, the response rate was $6 \%$ resulting in 622 participants.

Once the survey data was collected, the results were scrubbed of any personally identifiable information. Since the tool used for collecting survey feedback, Qualtrics, automatically collects the User ID Number (UID) of participants, the UIDs were immediately deleted. No other identifiable information was collected in the survey. To further protect the confidentiality of the student responses, the Qualtrics account was password protected and was only accessible to the researchers involved in the study. After three weeks of data collection, the survey was officially closed. The returned data was then analyzed for its descriptive characteristics and for any statistically significant differences between undergraduate and graduate students. Next, we discuss the data analysis.

\section{Data analysis}

The data was first analyzed for its descriptive characteristics based on frequency counts and percentages. To begin with, the distribution of respondents on demographic variables was examined relative to that of the sample and the actual student populations. The chi-square goodness of fit test using collapsed scales were used to determine if there were differences in responses between graduate and undergraduate students in technology use and their perceived value of different technologies for learning. Independent samples t-tests were also conducted to compare undergraduate and graduate responses to Likert style questions in the four categories identified in the previous research (e.g., Discussion, Collaboration \& Interaction, Experiential Learning, Personalization, and Organization and Resource Management). The results of these analyses are presented in the next section.

\section{RESULTS}

The results of this study are described by each of the research questions. Cronbach alpha for scaled items (Questions 5, 7-11) is .95 suggesting a high level of reliability of the instrument.

\section{Q1: What technologies do college students use most frequently for learning?}

As mentioned previously, Questions 4 and 6 surveyed students about what hardware and software tools they use to learn. From the perspective of hardware 
devices, laptops had the highest reported usage for learning (98\%). Mobile phones (smartphones) were close behind with $72 \%$ of participants reporting use. This is consistent with the findings of the Dabbagh and Fake (2017) study described earlier. On the other hand, only a small percentage of participants indicated that they used wearable technologies or streaming devices for learning ( $5 \%$ and $6 \%$, respectively, covered under "Other" in Figure 4).

Figure 4. Reported hardware use for learning

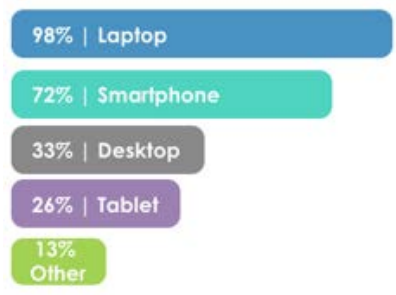

With respect to software or digital tools used for learning, search engines (99\%), file sharing tools (90\%), and digital libraries (88\%) were the most common. Videos (e.g., YouTube videos) (85\%) also ranked high for learning. Less popular software tools included podcasts (15\%), MOOCs (17\%), and blogs (22\%). These findings are also consistent with the Dabbagh and Fake (2017) study described earlier. See Figure 5 .

Figure 5. Reported software used for learning

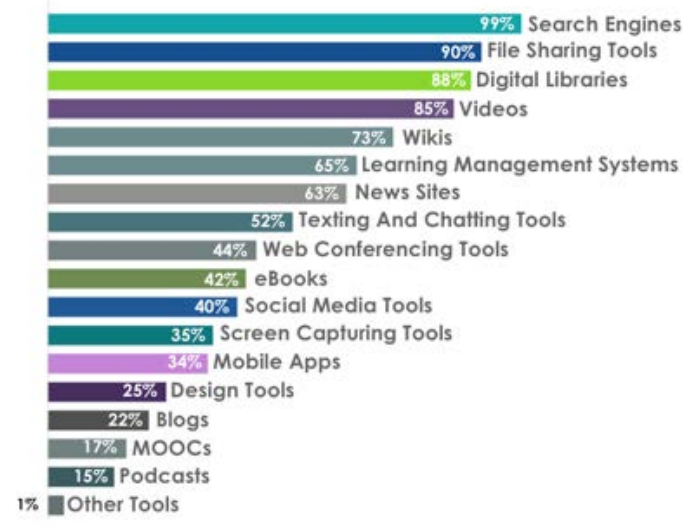




\section{Q2: What technologies do college students value for learning?}

Question 5 of the Technology Use for Learning Student Survey asked students about the value they ascribed to the hardware (devices) they used for learning. The responses indicated that students valued their laptops at the highest level with a striking majority (97\%) indicating that laptops were important or very important to their learning. Smartphones also emerged as valued learning devices with $64 \%$ of students indicating they felt that the device was important or very important for their learning. Consistent with the student reported frequency use, wearable technologies, and streaming devices were described as not important or not at all important. Only $6 \%$ of students agreed that wearable technologies were important or very important for learning and only $8 \%$ felt streaming devices were important or very important for learning. See Figure 6.

Figure 6. Importance of hardware used for learning

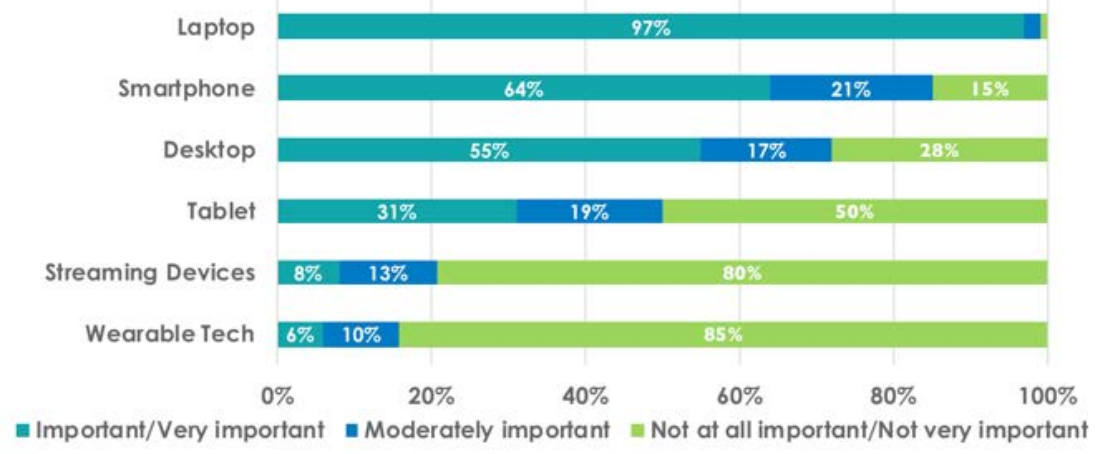

In addition to what hardware devices college students valued for learning, the survey inquired about the perceived importance of the following types of digital tools for learning: collaboration tools, progress tracking tools, visualization tools, experience and resource sharing tools, resource management and organizational tools, and design tools (see Appendix for examples of these tools). The results revealed that collaboration tools were considered to be the most important to students. Of those surveyed, $82 \%$ rated collaboration tools important or very important to the learning process followed by progress tracking tools (62\%). Design tools were found to be the least important within the given categories with $50 \%$ of students indicating they were important or very important to their learning. See Figure 7. 
Figure 7. Importance of tools for learning

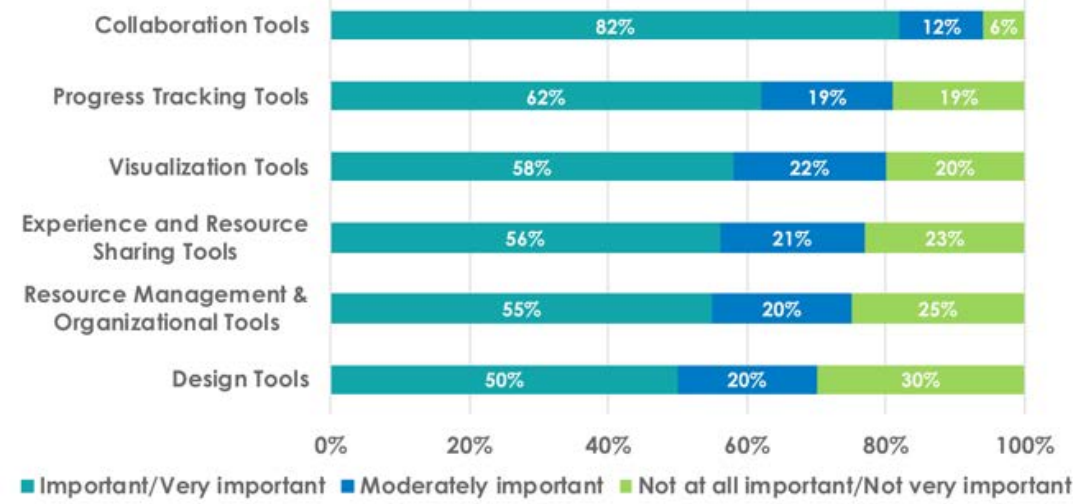

A Chi-square goodness of fit test was applied to data with collapsed scales (Important/Very Important vs. Moderately Important/Not very important/ Not at all important) to determine whether students' responses to questions regarding perceived technology value distribute differently by level (i.e., graduate vs. undergraduate). Results showed that undergraduate students valued their smartphone as an important device for learning at a statistically significant rate compared to graduate students (68\% undergraduate vs. $57 \%$ graduate, Important/ Very Important, $\mathrm{p}<.05$ ). On the other hand, a significantly higher percentage of graduate students valued their tablets as an important device for learning than undergraduate students (42\% graduate versus $24 \%$ undergraduate, Important/Very Important, $\mathrm{p}<.001)$.

\section{Q3: How effective are technologies in supporting learning?}

Questions 7-10 of the survey evaluated students' perceived effectiveness of learning technologies in supporting four areas. A majority of participants agreed or strongly agreed that technologies used for learning supported them in Discussion, Collaboration and Interaction (69\%), Experiential Learning (76\%), Personalization (71\%), and Organization, Planning, and Resource Management (76\%). See Figure 8. 
Figure 8. Reported effectiveness based on qualitative categories

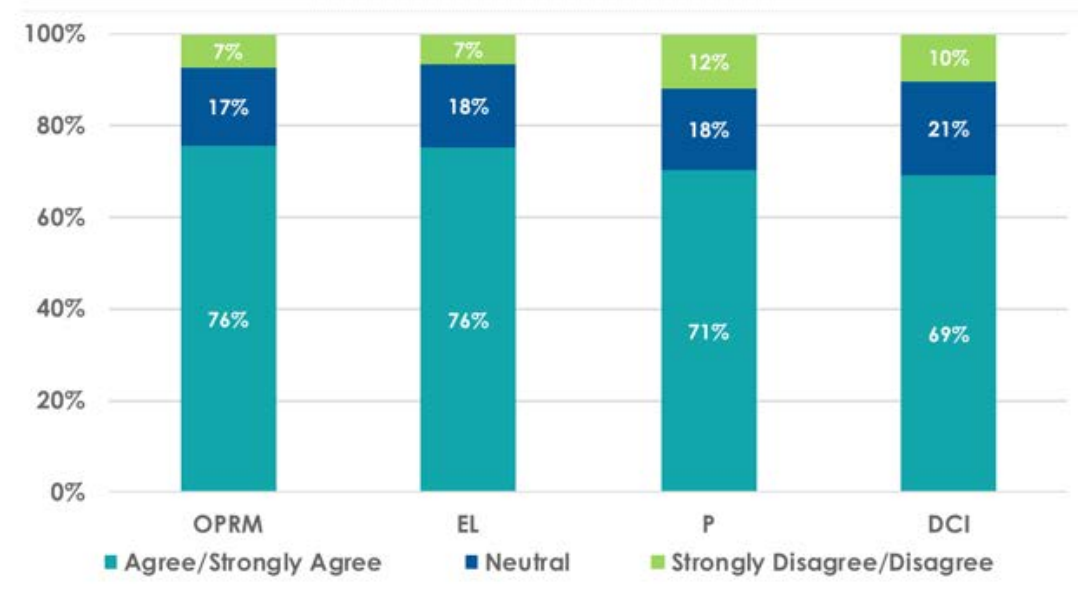

Within the aggregated categories, however, there were several statistically significant differences between undergraduate and graduate students regarding their perceived effectiveness of learning technologies. An independent-samples t-test indicated, scores were significantly higher for undergraduate students than graduate students for supporting their ability to "meet learners with similar interests" (DCI), "customize the user interface or visual display to suit my learning needs" (P), "monitor my progress towards achieving a learning goal" (OPRM), "evaluate my learning performance" (OPRM), "reflect on my learning performance" (OPRM), and "determine strategies to help me complete learning tasks" (OPRM). Graduate students, on the other hand, reported that technology "minimizes distractions" (P) at a statistically higher rate than undergraduates. All differences were significant at $\mathrm{p}<$.o5 level.

\section{CONCLUSIONS AND IMPLICATIONS}

The results of this study reveal a variety of implications regarding the use of technology in higher education contexts particularly as this relates to integrating Web 2.o and social media technologies as well as how teaching and learning practices should change as a result of the affordances of these technologies. One key finding of this research is that value seems to be closely aligned with usage. For example, laptops were overwhelmingly reported as the most used and the most valued devices for learning. Smartphones were also reported as highly used and important or very important to the learning process. These device choices indicate the importance to the modern day student of being able to use portable and mobile devices for learning. It also suggests that students are looking for opportunities to learn on the go or 
anytime, anywhere, without the constraints of a formal learning environment. This is further supported by the low-frequency reports (33\%) of students using desktop computers to support their learning. Higher education institutions can better serve students by supporting mobile devices.

Another key finding is that the top five types of software (digital tools) used for learning (search engines, file-sharing tools, digital libraries, videos, and wikis) suggests that learners are taking self-directed approaches to their learning that place them in the center of their learning process. Based on this behavioral trend, educators may need to support learners as they analyze the quality of these resources and lean into this informal means of information seeking behavior. It also may suggest that the traditional learning management system (LMS) may no longer serve as the best means for organizing or facilitating learning for an individual given that learners are embracing resources that extend beyond the traditional LMS.

Also of note, collaboration tools were perceived as the most important to surveyed participants, however, the level of agreement in the Discussion, Collaboration, and Interaction (DCI) category was the lowest of all the categories (69\%) in terms of the perceived effectiveness of technology in supporting these learning interactions. While $69 \%$ still represents a high level of agreement, the ascribed importance of collaboration tools may suggest that additional research and consideration is necessary to design better teaching strategies, tools, and instructional designs to support collaborative practices using technology. Future research should explore how to optimize the usability of collaborative technologies, how to structure collaborative learning experiences, and how to evaluate the effectiveness of collaboration tools for learning.

Another key finding from this research is that undergraduate and graduate students had different experiences with technology effectiveness. Undergraduate students tended to agree or strongly agree that technology supported Organization, Planning, and Resource Management (OPRM) at a higher level than graduates on a multitude of items. This finding is surprising given that students arriving at university usually have little experience or knowledge in the use of digital tools for learning or awareness of how Web 2.0 tools can be used for learning (Castaneda \& Soto, 2010). More research is needed to support this finding. Additionally, "manage my time" scored lower than the average in the category of OPRM for all respondents. Given the perceived importance the participants of this study ascribed to progress tracking tools, this provides an opportunity to identify tools and strategies to further support students in time management.

Overall, it is clear that college students value digital tools for learning and perceive technology as being effective in supporting their learning, however, the noted differences between undergraduate and graduate student populations provide opportunities for future research. From a pragmatic perspective, the results of this study may also help to identify areas of support from an institutional perspective. Since this study was conducted at a public university, the item level responses may indicate potential areas of focus for future initiatives. 


\section{REFERENCES}

Adams Becker, S., Cummins, M., Davis, A., Freeman, A., Hall Giesinger, C., \& Ananthanarayanan, V. (2017). NMC Horizon Report: 2017 Higher Education Edition. Austin, Texas: The New Media Consortium.

Adell, J., \& Castañeda, L. (2010). Los Entornos Personales de Aprendizaje (PLEs): Una nueva manera de entender el aprendizaje. En R. Roig Vila \& M. Fiorucci, (Eds.), Claves para la investigación en innovación y calidad educativas. La integración de las Tecnologías de la Información y la Comunicación y la Interculturalidad en las aulas. Stumenti di ricerca per l'innovaziones e la qualità in ámbito educativo. La Tecnologie dell'informazione e della Comunicazione e l'interculturalità nella scuola. Alcoy: Marfil - Roma TRE Universita degli studi.

Barron, B. (2006). Interest and self-sustained learning as catalysts of development: A learning ecology perspective. Human Development, 49(4), 193-224. doi:10.1159/000094368

Castañeda, L., \& Soto, J. (2010). Building Personal Learning Environments by using and mixing ICT tools in a professional way. Digital Education Review, 18, 9-25.

Dabbagh, N., Benson, A., Denham, A., Joseph, R., Al-Freih, M., Zgheib, G, . . . Guo,Z. (2016). Learning technologies and globalization: Pedagogical frameworks and applications. SpringerBriefs in Educational Communications and Technology. Cham, Switzerland: Springer International Publishing AG.

Dabbagh, N., \& Fake, H. (2017). College students' perceptions of Personal Learning Environments (PLEs) through the lens of digital tools, processes, and spaces. Journal of New Approaches in Educational Research, 6(1), 28-36. Retrieved from https://naerjournal. ua.es/article/view/v6n1-4
Dabbagh, N., \& Kitsantas, A. (2012). Personal Learning Environments, social media, and self-regulated learning: A natural formula for connecting formal and informal learning. The Internet and Higher Education, 15(1), 3-8. doi: http:// dx.doi.org/10.1016/j.iheduc.2011.06.002

Dabbagh, N., \& Kitsantas, A. (2013). The role of social media in self-regulated learning. International Journal of Web Based Communities (IJWBC), Special Issue, Social Networking and Education as a Catalyst Social Change, 9(2), 256273. doi: http://dx.doi.org/10.1504/ ijwbc.2013.053248

Dabbagh, N., Kitsantas, A., Al-Freih, M., \& Fake, H. (2015). Using social media to develop Personal Learning Environments (PLEs) and self-regulated learning skills: A case study. International Journal of Social Media and Interactive Learning Environments, 3(3), 163-183.

Dabbagh, N., \& Reo, R. (2011). Impact of Web 2.0 on higher education. In D. W. Surry, T. Stefurak, \& R. Gray (Eds.), Technology integration in higher education: Social and organizational aspects (174-187). Hershey, PA: IGI Global. doi: http:// dx.doi.org/10.4018/978-1-60960-147-8. cho13

Davis, M. (2008). Project $10 X$, semantic wave 2008 report: Industry roadmap to Web 3.0 \& multibillion dollar market opportunities. Retrieved from http://www.eurolibnet.eu/files/ REPOSITORY/20090507165103 SemanticWaveReport2008.pdf

Dede, C., \& Crimson, E. (2013). New technology-based models for postsecondary learning: Conceptual frameworks and research agendas. Paper presented at the National Science Foundation-Sponsored Computing Research Association Workshop, Boston, MA. Retrieved from http://archive2. 
cra.org/uploads/documents/resources/ rissues/Postseconday Learning NSFCRA report.pdf

Haskins, T. (2007, July 13). PLEs are power tools [web log post]. Retrieved from http://growchangelearn.blogspot. com/2007/06/ples-are-power-tools.html

Johnson, L., Adams, S., \& Haywood, K. (2011). The NMC horizon report: 2011 K-12 edition. Retrieved from http://www. nmc.org/pdf/2011- Horizon-Report-K12. pdf

Kitsantas, A., \& Dabbagh, N. (2010). Learning to learn with Integrative Learning Technologies (ILT): A practical guide for academic success. Greenwich, CT: Information Age Publishing. doi: http://dx.doi.org/10.1111/j.14679647.2012.00837.x

Martindale, T., \& Dowdy, M. (2010). Personal Learning Environments. In G. Veletsianos (Ed.), Emerging technologies in distance education (177-193). Edmonton, AB: Athabasca University Press.

Mason, R., \& Rennie, F. (2007). Using Web 2.o for learning in the community. The Internet and Higher Education, 10(3), 196-203. doi: http://dx.doi.org/10.1016/j. iheduc.2007.06.003

McLoughlin, C., \& Lee, M. J.W. (2010). Personalised and self-regulated learning in the Web 2.0 era: International exemplars of innovative pedagogy using social software. Australasian Journal of
Educational Technology, 26(1), 28-43. doi: http://dx.doi.org/10.14742/ajet.1100 Minocha, S., \& Kerawalla, L. (2011). University students' self-motivated blogging and development of study skills and research skills. In M. J. W. Lee, \& C. McLoughlin (Eds.), Web 2.o-based e-Learning: Applying social informatics for tertiary teaching (149-179). Hershey, PA: IGI Global. doi: http://dx.doi. org/10.4018/9781605662947.choo8

Pardo, A. (2013). Social learning graphs: Combining social network graphs and analytics to represent learning experiences. International Journal of Social Media and Interactive

Learning Environments, 1(1), 43-58. doi: 10.1504/IJSMILE.2013.051652.

Parra, B. (2016). Learning strategies and styles as a basis for building personal learning environments. International Journal of Educational Technology in Higher Education, 13(4). doi: 10.1186/ s41239-016-00o8-z.

U.S. Department of Education, Office of Educational Technology, Reimagining the Role of Technology in Education: 2017 National Education Technology Plan Update, Washington, D.C., 2017.

van Harmelen, M. (2008). Design trajectories: Four experiments in PLE implementation. Interactive Learning Environments, 16(1), 35-46. doi: http:// dx.doi.org/10.1080/10494820701772686

\section{ACADEMIC AND PROFESSIONAL PROFILE OF THE AUTHORS}

Nada Dabbagh is Professor and Director of the Division of Learning Technologies in the College of Education and Human Development at George Mason University. She received a PhD in Instructional Systems from The Pennsylvania State University. Her research explores the pedagogical ecology of technology mediated learning environments with the goal of understanding the social and cognitive consequences of learning systems design. Her publications focus on personal learning environments, problem-based learning, and online and blended learning. E-mail: ndabbagh@gmu.edu 
Helen Fake is a Ph.D. candidate at George Mason University where she is writing her dissertation on Personalized Learning in Workforce Training and Development Programs. Her research and publications focus on personalized learning, workforce training and development, and instructional design. She currently serves as the Lead User Experience Designer and Researcher at The Motley Fool and is also the CoFounder and CEO of Boom Dazzle, LLC., an instructional design consultancy. E-mail: hfake@gmu.edu

Zhicheng Zhang received a PhD in Educational Research from the University of Alabama and a MS in Computer Science from the University of Northern Virginia. Her publications include college students' metacognitive development, teacher assessment competencies (journal articles), research pathways and methodologies in institutional/survey research (book chapters). Her research also covers technology impact on student learning and course evaluation. She is currently serving as the Associate Director of Institutional Research and Effectiveness at George Mason University.

E-mail: zzhang11@gmu.edu

Address:

George Mason University

MSN 3D2, 4400 University Drive

Fairfax, VA 22030

Date of receipt: $23 / 05 / 2018$

Date of acceptance: $15 / 06 / 2018$

Date of layout: $13 / 10 / 2018$ 


\section{APPENDIX}

Technology Use For Learning Student Survey 2017-2018

\section{Research Consent}

I consent to participate in this online research survey. Additional information about this research project can be found here. (Agree/Disagree) (Disagree answer disqualifies tester)

\section{Please indicate your age.}
a. 17 or younger (disqualifies tester)
b. $18-21$
c. $22-30$
d. $31-40$
e. $41-50$
f. $50+$

2. Which of the following best describes your class standing during the current academic year?
a. Freshman or first-year student
b. Sophomore or second-year student
c. Junior or third-year student
d. Senior or fourth-year student
e. Fifth-year student or beyond
f. Graduate student
g. Doctoral student

3. In what area is your major? (Select the option that is the closest match to your primary major)
a. Agriculture and natural resources
b. Biological/life sciences
c. Business, management, marketing
d. Communications/journalism
e. Computer and information sciences
f. Education and training
g. Engineering and architecture
h. Fine and performing arts 
i. Health Sciences

j. Humanities

k. Liberal arts/general studies

1. Manufacturing, construction, repair, or transportation

$\mathrm{m}$. Physical sciences, including mathematical sciences

n. Public administration, legal, social, and protective services

o. Social sciences

p. Undecided

q. Other major not described above (please specify)

\section{What hardware do you use for learning? (Check all that apply)}
a. Laptop
b. Desktop
c. Smartphone
d. Tablet
e. Wearable technologies (e.g., smartwatch, Google glass, fitness device, headset)
f. Streaming Media Devices (e.g., Roku, Apple TV, Amazon Fire Stick)
g. Other (please specify)

\section{How important is each of the following devices for your learning?}

\begin{tabular}{|l|l|l|l|l|l|l|}
\hline & $\begin{array}{c}\text { Not } \\
\text { Applicable }\end{array}$ & $\begin{array}{c}\text { Not at all } \\
\text { important }\end{array}$ & $\begin{array}{c}\text { Not very } \\
\text { important }\end{array}$ & $\begin{array}{c}\text { Moderately } \\
\text { important }\end{array}$ & $\begin{array}{c}\text { Very } \\
\text { important }\end{array}$ & $\begin{array}{c}\text { Extremely } \\
\text { important }\end{array}$ \\
\hline Laptop & & & & & & \\
\hline Desktop & & & & & & \\
\hline Smartphone & & & & & & \\
\hline Tablet & & & & & & \\
\hline $\begin{array}{l}\text { Wearable } \\
\text { technology (e.g., } \\
\text { smartwatch, } \\
\text { Google glass, } \\
\text { fitness device, } \\
\text { headset) }\end{array}$ & & & & & & \\
\hline $\begin{array}{l}\text { Streaming } \\
\text { Devices (e.g., } \\
\text { Roku, Apple TV, } \\
\text { Amazon Fire } \\
\text { Stick) }\end{array}$ & & & & & & \\
\hline
\end{tabular}




\section{What software, apps, or digital tools do you use for learning? (Check all that apply)}
a. Wikis (e.g., Wikipedia, WordPress)
b. Web conferencing tools (e.g., Google Hangouts, Skype)
c. File sharing tools (e.g., Google Docs, iCloud, Google Drive)
d. Design tools (e.g., Adobe Creative Suite, Piktochart, Powtoon)
e. News sites (e.g., BBC, New York Times, CNN)
f. Search engines (e.g., Google Chrome, Mozilla Firefox, Safari)
g. Digital libraries (e.g., EBSCO, Mason Library Databases, ProQuest)
h. Social media tools and social networks (e.g., Twitter, Facebook, LinkedIn)
i. Videos (e.g., YouTube, Lynda.com, TED Talks, instructional videos)
j. Blogs
k. Learning Management Systems (e.g., Google Classroom, Moodle, Blackboard)
1. Mobile Apps (e.g., Duolingo, Kindle)
m. eBooks
n. Podcasts
o. Massive Open Online Courses (MOOCs) (e.g., Coursera, Udacity, iTunes U, MIT Free Courses)
p. Screen capturing tools (e.g., SnagIt, snipping tool)
q. Texting and chatting tools (e.g., Google Chat, SMS, WhatsApp)
r. Other (please specify)

The next four questions (Q7, Q8, Q9, and Q10) seek to understand the extent to which you think technology has enabled your learning. While the questions are the same, the statements within the question will differ. Consider your experience over the past year with learning technologies, and rate your level of agreement with the statements under each question.

\section{Technology used for learning has enabled me to...}

\begin{tabular}{|l|l|l|l|l|l|l|}
\hline \multicolumn{1}{|c|}{ Statement } & $\begin{array}{c}\text { Don't } \\
\text { Know }\end{array}$ & $\begin{array}{l}\text { Strongly } \\
\text { Disagree }\end{array}$ & Disagree & Neutral & Agree & $\begin{array}{c}\text { Strongly } \\
\text { Agree }\end{array}$ \\
\hline $\begin{array}{l}\text { Feel connected to other } \\
\text { learners }\end{array}$ & & & & & & \\
\hline Feel connected to experts & & & & & & \\
\hline $\begin{array}{l}\text { Communicate and } \\
\text { collaborate on learning } \\
\text { tasks }\end{array}$ & & & & & & \\
\hline $\begin{array}{l}\text { Receive feedback about my } \\
\text { learning performance }\end{array}$ & & & & & & \\
\hline
\end{tabular}




\begin{tabular}{|l|l|l|l|l|l|l|}
\hline \multicolumn{1}{|c|}{ Statement } & $\begin{array}{l}\text { Don't } \\
\text { Know }\end{array}$ & $\begin{array}{l}\text { Strongly } \\
\text { Disagree }\end{array}$ & Disagree & Neutral & Agree & $\begin{array}{c}\text { Strongly } \\
\text { Agree }\end{array}$ \\
\hline $\begin{array}{l}\text { Discuss my learning with } \\
\text { others }\end{array}$ & & & & & & \\
\hline $\begin{array}{l}\text { Ask others questions } \\
\text { associated with my } \\
\text { learning }\end{array}$ & & & & & & \\
\hline $\begin{array}{l}\text { Explain my thought } \\
\text { process to others }\end{array}$ & & & & & & \\
\hline $\begin{array}{l}\text { Develop relationships } \\
\text { outside of my immediate } \\
\text { community }\end{array}$ & & & & & & \\
\hline $\begin{array}{l}\text { Meet learners with similar } \\
\text { interests }\end{array}$ & & & & & & \\
\hline
\end{tabular}

\section{Technology used for learning has enabled me to...}

\begin{tabular}{|l|l|l|l|l|l|l|}
\hline \multicolumn{1}{|c|}{ Statement } & $\begin{array}{l}\text { Don't } \\
\text { Know }\end{array}$ & $\begin{array}{l}\text { Strongly } \\
\text { Disagree }\end{array}$ & Disagree & Neutral & Agree & $\begin{array}{c}\text { Strongly } \\
\text { Agree }\end{array}$ \\
\hline $\begin{array}{l}\text { Work with others on a } \\
\text { project }\end{array}$ & & & & & \\
\hline $\begin{array}{l}\text { Build relevant skills that } \\
\text { are useful outside the } \\
\text { classroom }\end{array}$ & & & & & & \\
\hline $\begin{array}{l}\text { Connect formal course } \\
\text { materials and real-world } \\
\text { experiences }\end{array}$ & & & & & & \\
\hline $\begin{array}{l}\text { Complete tangible projects } \\
\text { that could be highlighted } \\
\text { in a portfolio or resume }\end{array}$ & & & & & & \\
\hline $\begin{array}{l}\text { Feel confident about } \\
\text { tackling real-world tasks }\end{array}$ & & & & & & \\
\hline $\begin{array}{l}\text { Reflect on how to improve } \\
\text { a project in the future }\end{array}$ & & & & & & \\
\hline $\begin{array}{l}\text { Experiment, iterate and } \\
\text { test different solutions } \\
\text { to problems facing } \\
\text { professionals in the } \\
\text { industry }\end{array}$ & & & & & & \\
\hline $\begin{array}{l}\text { Try new behaviors, skills, } \\
\text { and attitudes }\end{array}$ & & & & & & \\
\hline
\end{tabular}




\section{Technology used for learning has enabled me to...}

\begin{tabular}{|l|l|l|l|l|l|l|}
\hline \multicolumn{1}{|c|}{ Statement } & $\begin{array}{l}\text { Don't } \\
\text { Know }\end{array}$ & $\begin{array}{l}\text { Strongly } \\
\text { Disagree }\end{array}$ & Disagree & Neutral & Agree & $\begin{array}{c}\text { Strongly } \\
\text { Agree }\end{array}$ \\
\hline Learn at my own pace & & & & & & \\
\hline Learn anytime, anywhere & & & & & & \\
\hline $\begin{array}{l}\text { Customize the user } \\
\text { interface or visual display } \\
\text { to suit my learning needs }\end{array}$ & & & & & & \\
\hline $\begin{array}{l}\text { Select how learning } \\
\text { materials are presented to } \\
\text { me (e.g., video or text) }\end{array}$ & & & & & & \\
\hline Minimize distractions & & & & & & \\
\hline $\begin{array}{l}\text { Access learning materials } \\
\text { that interest me }\end{array}$ & & & & & & \\
\hline $\begin{array}{l}\text { Access learning materials } \\
\text { based on my previous web } \\
\text { activity }\end{array}$ & & & & & & \\
\hline $\begin{array}{l}\text { Reduce obstacles to } \\
\text { learning when compared } \\
\text { to a formal setting }\end{array}$ & & & & & & \\
\hline
\end{tabular}

\section{Technology used for learning has enabled me to...}

\begin{tabular}{|l|l|l|l|l|l|l|}
\hline \multicolumn{1}{|c|}{ Statement } & $\begin{array}{l}\text { Don't } \\
\text { Know }\end{array}$ & $\begin{array}{l}\text { Strongly } \\
\text { Disagree }\end{array}$ & Disagree & Neutral & Agree & $\begin{array}{c}\text { Strongly } \\
\text { Agree }\end{array}$ \\
\hline $\begin{array}{l}\text { Set learning goals for } \\
\text { myself }\end{array}$ & & & & & & \\
\hline Manage my time & & & & & & \\
\hline $\begin{array}{l}\text { Monitor my progress } \\
\text { towards achieving a } \\
\text { learning goal }\end{array}$ & & & & & & \\
\hline $\begin{array}{l}\text { Evaluate my learning } \\
\text { performance }\end{array}$ & & & & & & \\
\hline $\begin{array}{l}\text { Reflect on my learning } \\
\text { performance }\end{array}$ & & & & & & \\
\hline $\begin{array}{l}\text { Determine strategies to } \\
\text { help me complete learning } \\
\text { tasks }\end{array}$ & & & & & & \\
\hline
\end{tabular}




\begin{tabular}{|l|l|l|l|l|l|l|}
\hline \multicolumn{1}{|c|}{ Statement } & $\begin{array}{c}\text { Don't } \\
\text { Know }\end{array}$ & $\begin{array}{l}\text { Strongly } \\
\text { Disagree }\end{array}$ & Disagree & Neutral & Agree & $\begin{array}{c}\text { Strongly } \\
\text { Agree }\end{array}$ \\
\hline $\begin{array}{l}\text { Organize my learning } \\
\text { resources }\end{array}$ & & & & & & \\
\hline Prioritize learning tasks & & & & & & \\
\hline $\begin{array}{l}\text { Aggregate all of my } \\
\text { information in one place }\end{array}$ & & & & & & \\
\hline $\begin{array}{l}\text { Document my work and } \\
\text { projects }\end{array}$ & & & & & & \\
\hline
\end{tabular}

\section{How important are the following digital tools for supporting your learning?}

\begin{tabular}{|c|c|c|c|c|c|c|}
\hline & $\begin{array}{l}\text { Don't } \\
\text { know }\end{array}$ & $\begin{array}{l}\text { Not at all } \\
\text { important }\end{array}$ & $\begin{array}{l}\text { Not very } \\
\text { important }\end{array}$ & $\begin{array}{c}\text { Moderately } \\
\text { important }\end{array}$ & $\begin{array}{c}\text { Very } \\
\text { important }\end{array}$ & $\begin{array}{l}\text { Extremely } \\
\text { important }\end{array}$ \\
\hline $\begin{array}{l}\text { Resource } \\
\text { Management and } \\
\text { Organizational } \\
\text { Tools - } \\
\text { Technologies that } \\
\text { allow you to manage } \\
\text { learning resources. } \\
\text { For example, a } \\
\text { social bookmarking } \\
\text { tool may help you } \\
\text { aggregate, save, or } \\
\text { store online content } \\
\text { for the future (e.g., } \\
\text { Evernote, OneNote, } \\
\text { etc.). }\end{array}$ & & & & & & \\
\hline
\end{tabular}




\begin{tabular}{|c|c|c|c|c|c|c|}
\hline & $\begin{array}{l}\text { Don't } \\
\text { know }\end{array}$ & $\begin{array}{l}\text { Not at all } \\
\text { important }\end{array}$ & $\begin{array}{l}\text { Not very } \\
\text { important }\end{array}$ & $\begin{array}{l}\text { Moderately } \\
\text { important }\end{array}$ & $\begin{array}{c}\text { Very } \\
\text { important }\end{array}$ & $\begin{array}{l}\text { Extremely } \\
\text { important }\end{array}$ \\
\hline $\begin{array}{l}\text { Progress } \\
\text { Tracking Tools } \\
\text { - Technologies } \\
\text { that enable you to } \\
\text { track your progress } \\
\text { towards attaining } \\
\text { learning goals over } \\
\text { time (e.g., mobile } \\
\text { checklists, reminder } \\
\text { apps, etc.) }\end{array}$ & & & & & & \\
\hline $\begin{array}{l}\text { Collaboration } \\
\text { Tools - } \\
\text { Technologies } \\
\text { that enable you } \\
\text { to communicate } \\
\text { with others and } \\
\text { cooperate towards } \\
\text { a shared goal (e.g., } \\
\text { Google Drive, } \\
\text { Slack, Dropbox, } \\
\text { SharePoint, Google } \\
\text { Hangout, etc.) }\end{array}$ & & & & & & \\
\hline $\begin{array}{l}\text { Visualization } \\
\text { Tools - } \\
\text { Technologies that } \\
\text { allow you to display } \\
\text { information in } \\
\text { different ways to } \\
\text { find new patterns or } \\
\text { trends (e.g., Mind- } \\
\text { Mapping software, } \\
\text { Google Charts, etc.) }\end{array}$ & & & & & & \\
\hline $\begin{array}{l}\text { Design Tools - } \\
\text { Technologies that } \\
\text { allow you to create } \\
\text { digital materials } \\
\text { and prototypes } \\
\text { (e.g., Photoshop, } \\
\text { Illustrator, Sketch, } \\
\text { etc.) }\end{array}$ & & & & & & \\
\hline
\end{tabular}


N. DABBAGH; H. FAKE; Z. ZhANG

STUDENT PERSPECTIVES OF TECHNOLOGY USE FOR LEARNING IN HIGHER EDUCATION

\begin{tabular}{|c|c|c|c|c|c|c|}
\hline & $\begin{array}{l}\text { Don't } \\
\text { know }\end{array}$ & $\begin{array}{l}\text { Not at all } \\
\text { important }\end{array}$ & $\begin{array}{l}\text { Not very } \\
\text { important }\end{array}$ & $\begin{array}{c}\text { Moderately } \\
\text { important }\end{array}$ & $\begin{array}{c}\text { Very } \\
\text { important }\end{array}$ & $\begin{array}{l}\text { Extremely } \\
\text { important }\end{array}$ \\
\hline $\begin{array}{l}\text { Experience } \\
\text { and Resource } \\
\text { Sharing Tools - } \\
\text { Technologies that } \\
\text { enable you to create } \\
\text { and share content as } \\
\text { well as connect with } \\
\text { other learners (e.g., } \\
\text { Twitter, Facebook, } \\
\text { Reddit, etc.) }\end{array}$ & & & & & & \\
\hline
\end{tabular}

Thank you for participating in this survey! 